Quantitative Political Economy Research Group

Department of Political Economy

King's College London

\title{
QPE
}

\section{The Brexit Referendum and Three Types of Regret}

QPE Working Paper 2021-35

Stephen Drinkwater

Colin Jennings

July 13, 2021 


\title{
The Brexit Referendum and Three Types of Regret
}

\author{
Stephen Drinkwater ${ }^{1}$
}

Colin Jennings ${ }^{2}$

\author{
${ }^{1}$ Business School, University of Roehampton London. \\ Wales Institute of Social and Economic, Research, Data and Methods. \\ ${ }^{2}$ Department of Political Economy, King's College London.
}

\begin{abstract}
In this paper we examine three forms of regret in relation to the UK's hugely significant referendum on EU membership that was held in June 2016. These are, (i) whether leave voters at the referendum subsequently regretted their choice (in the light of the result), (ii) whether non-voters regretted their decisions not to vote (remain) and (iii) whether individuals were more likely to indicate that it is everyone's duty to vote following the referendum. We find evidence in favour of all three types of regret. In particular, leave voters and non-voters were significantly more likely to indicate that they would vote remain given their chance to do so again and there was a significant increase in the probability of an individual stating that it was everyone's duty to vote in a general election in 2017 compared to 2015.
\end{abstract}

Key Words: EU Referendum; Brexit; Voting; Regret; Non-Voters.

JEL Classifications: D70; D72; F60.

Acknowledgements: The British Social Attitudes survey has been provided through the UK Data Service (UKDS). We would also like to thank Damien Bol, Samuel Brown, Gabriel Leon and Ruben Ruiz-Rufino for helpful comments. 


\section{Introduction}

This paper contributes to the large and growing literature spawned by the UK's decision to leave the EU in 2016 or Brexit. A central focus has been on the characteristics of leave and remain voters and theories as to what caused voters to vote as they did. The outcome of the referendum was perceived by most people as a shock, including many ardent leavers and most experts argued (and still do) that Brexit will be costly for the citizens of the UK. ${ }^{1}$ Identifying the characteristics of voters and explaining how they voted has clearly been the main focus of research on the ballot itself (Clarke et al, 2017; Sobolewska and Ford, 2020). A common argument made in some media is that because remain was expected to win, many leave voters registered a protest vote to leave and regretted it afterwards. ${ }^{2}$ Using the British Social Attitudes Survey (BSAS), we will study this, but also shift focus towards those who did not vote in the referendum. Another common argument made after the referendum was that non-voters could have changed the outcome to remain had they voted. ${ }^{3}$ In particular, frustration was often expressed among remain voters concerning younger people not voting in the proportion that older people did, because younger voters predominantly associate with remain and older voters are more associated with leave. ${ }^{4}$

If there is a very high level of regret after an election or referendum, serious concerns must be raised as to how we are to interpret the regretful democratic verdict that has been delivered. It should be seen as a matter of significant importance to establish levels of regret following elections and referendums, especially for referendums given that they are generally one-off events and unlike elections do not provide an opportunity to correct for mistakes at the next ballot. For the Brexit referendum, we can see two types of post referendum regret are often posited. First, that leave voters regret voting leave. This proposition, while widely stated, has been hard to sustain as a source of regret. ${ }^{5}$ While it may be that survey respondents do not wish to acknowledge their regret, we do still find some evidence that leave voters would be more likely than remainers to switch in a new ballot. However, the second form of regret attributed to non-voters can be more clearly established, and it comes in two forms, one familiar and one not.

The familiar form of regret is that non-voters would now vote by a significant number in a new referendum and that a majority of this group of new voters would vote remain. The less familiar form of regret concerns voter motivation. Not surprisingly non-voters were much less likely than voters in the referendum to state duty as a motive for voting. We show that non-voters appear to substantially revise their own attitudes to voting after 2016 with a significant increase in those stating duty as a motive for voting. Therefore, an indirect effect of the Brexit referendum is the effect it may have had on attitudes to voting. If Brexit

\footnotetext{
1 'How the pollsters got it wrong on the EU referendum', The Guardian, 24 June 2016.

2 'I thought I'd put in a protest vote': the people who regret voting leave', The Guardian, 25 November 2017.

${ }^{3}$ The turnout at the referendum was $72.2 \%$.

4 'Young people are so bad at voting - I'm disappointed in my peers', The Guardian, 28 June 2016.

5 'Have UK voters changed their mind on Brexit', John Curtice, UK in a Changing Europe, 17 October 2019.
} 
triggered an increase in a sense of duty (especially amongst the young) this could have significant effects on the turnout of future elections and their outcomes. Of course, any change in voting attitude may be short-lived but it is also possible that Brexit may have been a shock from which the after-effects persist not just economically and politically but also in terms of attitudes to democratic participation which would in turn feed into future politics and economics.

An important question is whether the sources of regret that we identify would be sufficient to overturn the result of 2016. Clearly, data taken from survey results must be treated with caution and a (very unlikely) fresh referendum would, no doubt, trigger passions in a way that cannot be predicted in advance. However, we show that a significant majority surveyed claim they would vote remain in a new referendum and this we argue is driven by leave voters being more likely to switch to remain than vice versa; by non-voters in 2016 being significantly more likely to vote and vote remain and that an increased sense of duty may contribute to higher turnout amongst those that support remain.

The paper is organised as follows. In the next section we discuss the related Brexit literature. In section 3 we provide a simple theoretical approach and discuss the related literature that helps us construct the hypotheses to be tested. We then conduct the empirical analysis in sections 4 to 6 and finish with some concluding comments.

\section{Related Brexit Literature}

Broadly two types of literature have emerged from the referendum. The first is concerned with the characteristics of those that voted and theories as to why they voted the way that they did. The second literature is concerned with the consequences of Brexit in terms of future EU-UK relations, UK relationships with the rest of the world and the implications for the future of the UK economy, governance and indeed the sustainability of the UK itself (Aidt et al, 2021; Born et al, 2019; Chen et al, 2018; Johnson and Mitchell, 2017; Sampson, 2017). The analysis presented here falls in the first group by focusing on the referendum itself with attention also to the characteristics and motivation of non-voters. However, it also touches into discussion about the future if the referendum triggered attitudinal changes with regard to voting.

The contrasting characteristics of leave versus remain supporters has been shown in a number of papers. Various studies confirm that low education, low incomes and older age were strong predictors of voting leave (Alabrese et al, 2019, Arnasson and Zoega 2018). Alabrese et al (2019) point to further leave voting factors such as white ethnicity, infrequent use of smartphones and the internet, receipt of benefits, adverse health and low life satisfaction. The last of these issues is also studied in Powdthavee et al (2019) and Carreras et al (2019) who use prospect theory to explain why voters who feel they have little to lose are more willing to take economic risks by voting for Brexit. This stands, in contrast, with Clarke et al (2017) who find younger people being significantly more likely to emphasise the risks of Brexit. 
Hobolt et al (2021) demonstrate the extent to which the referendum solidified identities and intensified polarisation.

There is a rich literature which focuses more on reasons why voters vote remain and especially leave. Norris and Ingelhart (2019) while acknowledging they are not completely separable distinguish between economic insecurity and cultural backlash. On economic insecurity Fetzer (2019) argues that had it not been for austerity remain would have won. Liberini et al (2019) argue that age is not as strong a predictor as is often thought, with only the very young being clearly predictable as pro remain. They argue that economic insecurity is more clear-cut in predicting leave. Several authors point to the long run effects of globalisation on industrial structure and culture such as Colantone and Stanig (2018) who analyse the role of import shocks from China and leave voting. They also argue these votes are primarily sociotropic rather than a pocket-book response.

Concerns about immigration fall under both economic insecurity and cultural backlash and this influence on voting leave is highlighted in Hobolt (2016) and Ford and Goodwin (2017). This is a contested area as many leave voting areas have relatively few immigrants, in contrast with some of the strongest urban remain areas. Goodwin and Milazzo (2017) argue that the key factor is the rate of immigration at the local level and the perceived lack of control over it. Carreras (2019) argues that economic insecurity converts into cultural backlash, by showing that British citizens living in economically depressed and declining districts are more likely to develop cultural grievances and especially anti-immigrant and Eurosceptic views. ${ }^{6}$ The merging of economics and culture is also evident in Green et al (2021) who argue that economic concerns impacted on Brexit through the perceived relative gains and losses of social groups.

An important point, however, is that while clear demographic characteristics of leave versus remain voters and non-voters as a third category can be identified and that clear underlying motives for voting leave, remain and not voting are identifiable, the question of the seriousness of conviction lurks in the background. Specifically, what if leave voters and nonvoters regret their decision not to vote remain? A large number might argue that had they known on 23 June, 2016 that the referendum would be so close they would have voted and voted remain. Goodwin et al (2020) examine the impact that campaign effects had on the EU referendum and find that the arguments in favour of EU membership were understated. If large scale regret is expressed, it calls into question how we should interpret the implications of the empirical work on the demographic characteristics and motivations of leave voters and non-voters. For example, should we be as quick to conclude that immigration is as major a concern as the leave vote would suggest if leave voters regret their choice, or that the identity with the European Union is weak among the young if they regret not voting?

\footnotetext{
${ }^{6}$ Schwartz et al (2021) report the attitudes towards immigrants became more positive after the referendum.
} 


\section{Theoretical Background}

The theoretical basis for our paper lies in the interplay of two related but distinct concepts, regret and the motivation of voters. In the rational choice literature, the idea of regret can be theoretically employed as an ex ante or ex post concept. Ferejohn and Fiorina (1974) used anticipation of regret to explain higher turn-out in elections than standard rational choice analysis would predict. The other form of regret, which this paper follows, is ex post as analysed by Bol et al (2018). They find high levels of regret after the 2015 Canadian general election. This setting is, of course, quite different to a binary referendum. Constituencies are contested by multiple parties and a voter's favourite party may not be competitive in their constituency which may provoke them to vote strategically for their most favoured party of those which are competitive. Bol et al (2018) use a mixed-utility model incorporating both instrumental and expressive preferences. The distinction is well established now in voting models (see Hamlin and Jennings, 2011 and 2019). Instrumental preferences concern how a voter will be affected by the policies of the winning party or position and will be weighted in the voting decision by the voter's expected probability of being decisive in determining the outcome of the election. This is an indirect benefit such that the voter votes for $\mathrm{x}$ to obtain a benefit $\mathrm{z}$. An expressive benefit is the direct benefit from voting for $\mathrm{x}$ unrelated to any instrumental benefits. Bol et al (2018) identify two forms of regret. The first is when a voter votes expressively for their favourite party $\mathrm{x}$ but regrets doing so because the election proved close and their least favourite of the competitive parties won the seat. The second is when a voter votes strategically (instrumentally) for y, but regrets doing so because y either won or lost by a large margin and they would have been better off voting expressively for their favourite, though uncompetitive, party $x$.

The referendum setting is clearly different to the Canadian election in that it is binary, but we can see that the first type of regret is potentially relevant. In this case, a voter may expressively vote for Brexit, but regret the choice because the referendum was close. That is, their instrumental and expressive preferences pulled in different directions. A realisation that that instrumental concerns were in retrospect more serious than they realised may be sufficient to ex post weigh instrumental concerns more heavily than they had been weighed ex ante when the decision to vote leave was made expressively.

In addition to instrumental and expressive benefits, a third type of potential voting benefit is satisfying a sense of duty. The focus on duty stems from Riker and Ordeshook (1968) and can be a crucial factor in determining whether to vote or not. As Blais and Galais (2016) explain, duty is different to instrumental and expressive concerns as it is unrelated to identifying with issues or party positions. If the sense of duty is strong enough a citizen will vote and how they vote will then be determined by instrumental and expressive concerns. For those that did not vote in the Brexit referendum, a rational choice model would suggest that instrumental and expressive benefits and a sense of duty were too small to overcome the cost of voting. Research by Hur (2017) and Goodman (2018) suggests that duty may be highly dependent upon context. Goodman discusses the idea of 'conditional duty'. She argues that the sense of duty to participate in an election will be affected by factors such as whether the 
stakes are high, how close the election is perceived to be and whether there are major differences in parties or positions. In the context of the Brexit referendum, going into it many non-voters did not think it would be close (expecting remain to win) and possibly did not see major differences in positions (after all, many leave campaigners argued for maintaining very close alignment with the EU). ${ }^{7}$ After the referendum, non-voters on observing how close the referendum was and that the possibility of 'hard Brexit' became very real may have revised their sense of duty upwards. The BSAS contains questions on motives to vote which includes duty. ${ }^{8}$ In our empirical section we investigate if after the Brexit referendum there was increased reporting of duty as a motive to vote.

We now formulate the three forms of regret that we will test empirically. We use a rational choice model containing the four components of discounted instrumental benefits, expressive benefits, duty and the cost of voting. A voter will vote for Brexit rather than remain if

$$
p\left(I_{B}-I_{R}\right)+\left(X_{B}-X_{R}\right)>0
$$

where $p$ is the probability of being decisive, $I_{B}$ and $I_{R}$ are the instrumental payoffs from Brexit and Remain, and $X_{B}$ and $X_{R}$ are their expressive payoffs.

Regret Type 1: The first form of regret concerns voters who voted for Brexit but would now vote Remain.

This could happen because at the time of the referendum $X_{B}>X_{R}$ and $I_{B}-I_{R}<0$ but $p$ is perceived to be so small that $I_{B}-I_{R}$ is largely discounted. In addition, before the referendum the gap between $I_{B}$ and $I_{R}$ may have been viewed as smaller than it came to be viewed after the referendum because hard Brexit was not expected or understood. Therefore, after the referendum, the sign of (1) is reversed to negative as $p$ is viewed as larger and $I_{B}-I_{R}$ more strongly negative.

Regret Type 2: The second form of regret concerns non-voters regretting not voting and not voting remain.

Here we do not need to consider conflicted voters in that their instrumental and expressive preferences are in opposition. We depict a non-voter who instrumentally and expressively favours remain. However, they do not vote because the following holds

$$
p\left(I_{R}-I_{B}\right)+X_{R}+D<C
$$

\footnotetext{
${ }^{7}$ fullfact.org/europe/what-was-promised-about-customs-union-referendum/

${ }^{8}$ Drinkwater and Jennings (2007) used this question to help identify who might be labelled 'expressive voters.'
} 
where $\mathrm{D}$ is duty and $\mathrm{C}$ is the cost of voting. Here the summation of the three types of voting benefits is insufficient to overcome the cost of voting. ${ }^{9}$ First, we can identify a regretful nonvoter for remain on instrumental and expressive issue dimensions. These might be an appreciation, as discussed earlier, that $p$ and the gap between $I_{R}$ and $I_{B}$ are larger than was thought at the time of the referendum. If the non-voter took the EU for granted, they may have underestimated their expressive attachment to the EU in the style of 'you don't what you've got till it's gone'. So $X_{R}$ is revised upwards. These issue related reflections may be sufficient to change the sign of (2).

Regret Type 3: The third form of regret is that after the 2016 referendum there is a significant increase in citizens giving duty as an answer when asked about motivation to vote.

Following our earlier discussion of conditional duty, the reflection that the referendum was high stakes, close and that there were major differences in positions may cause D to increase in (2). Empirically, we separate this from the questions of how respondents would vote (or not) in a fresh referendum. Instead, we check to see if there is a significant increase in respondents giving duty as a motivation for voting after 2016 .

\section{Data}

Our data have been obtained from the $B S A S$, which provides a representative sample of adults living in Great Britain. The 2017, 2018 and 2019 surveys all contained questions on whether respondents had voted in the EU Referendum as well as on how they voted. In addition, respondents were asked how they would vote if they were given the chance to vote again in the EU Referendum. Therefore, we use information from each of these surveys by combining responses across the years in our analysis. A question on the view of voting (in a General Election) has also been included in several years of $B S A S$ data. ${ }^{10}$

Table 1 presents a cross-tabulation of how respondents would vote in a referendum split by each survey year against whether they voted in the referendum. ${ }^{11}$ The table shows all answers to these questions including the respondents who indicated that they preferred not to say, didn't know/refusal and didn't remember with regards to whether they voted in the referendum - 59 out of 4,994 respondents in the latter. Only $1.7 \%$ of respondents who voted in the referendum reported that they would not vote in another referendum. This compares to almost $29 \%$ of those who did not vote in the referendum. In terms of the data presented in Table $1,56 \%$ of those that would vote if given the chance in a new referendum would vote remain and $44 \%$ would vote leave.

\footnotetext{
${ }^{9}$ Rudolph (2020) applies the Riker and Ordershook (1968) framework with regards to rainfall increasing the cost of voting function within the context of the 2016 Brexit vote.

10 The exact questions included in the surveys are reported in the Appendix. The questions on whether and how voted in the EU referendum were only asked to around a third of the full sample of respondents in 2018 and 2019. All of the interviews were carried out between July and November in each of the survey years.

${ }^{11}$ This table uses unweighted data, as does the rest of the analysis in the paper.
} 
Table 2 reports how respondents would vote against how they actually voted in the referendum. Again, the table includes all responses to these questions. It reveals that the vast majority of individuals would vote in the same way as they did in the EU Referendum if they were given the chance to do so again. In particular, around $93 \%$ of remain voters would have voted in that way again. The equivalent percentage was slightly lower for leave voters at $85 \%$. Just under $9 \%$ of this group indicated that they would vote remain if given a chance to do so and just over $2 \%$ that they would not vote again and just under $3 \%$ did not know or refused to say.

\section{Empirical Modelling}

With regards to the first type of regret, a binary logit model relating to whether respondents who voted in the referendum is estimated to identify those voters who would have voted differently if they were given the chance to do so again. Therefore, the dependent variable takes a value of one if those who voted at the EU referendum would have voted in a different way in a second referendum (for example, leave voters in the EU referendum who would have voted remain if they had the chance to do so again or vice versa) and zero for respondents who would have voted in the same way again. The key explanatory variable in this model relates to a dummy that takes a value of one if the respondent voted leave at the EU referendum and zero if they voted to remain. The model also contains controls for a standard set of socio-economic characteristics, especially those that have been found to be important in empirical studies of voting at the EU referendum. Specifically, these are gender, age, education, region, marital status, children in household, ethnicity, religion and economic position.

In order to test for the second type of regret outlined in the theoretical background section, we initially estimate multinomial logit models in which the dependent variable that relates to how the respondent would vote if given the chance to do so again takes one of three values. These are: (1) to remain in the EU, (2) leave or (3) that they would not vote. Those individuals who indicated that they preferred not to say, did not know or refused have been excluded from the models that have been estimated. The first model that is estimated includes individuals who voted in the EU referendum as well as those who did not, with a dummy variable included to identify the latter group. Therefore, this is a pooled model that combines voters and non-voters. ${ }^{12}$

A second set of multinominal logit models using the same dependent variable is then estimated separately for voters and non-voters, with controls included for views about voting (in a general election). ${ }^{13}$ Given the focus of our types of regret, we are also interested in the impact of respondents who thought it should be people's duty to vote. Table A1 in the Appendix reports responses to this question in every year that it was asked since $2000 .{ }^{14}$ This

\footnotetext{
${ }^{12}$ Those who gave a different answer to the question on whether voted in the EU referendum have been excluded from the econometric analysis.

${ }^{13}$ Only 41 respondents who voted in the EU referendum indicated that they wouldn't vote again. This represents a lower proportion of this group than those who gave a Don't Know or Refusal response: $1.7 \%$ versus $2.7 \%$ as indicated in Table 1.

${ }^{14}$ This question has not excluded from several surveys including those conducted in 2018 and 2019.
} 
shows that the percentage who thought it should be everyone's duty to vote in a general election has increased since 2009, having fallen by just almost 7 percentage points from its 2005 level. In particular, the percentage of respondents giving a positive response who indicated that it is everyone's duty to vote increased from less than $68 \%$ in 2015 to over $72 \%$ in 2017. The percentage of respondents in the other two categories, people should only vote if they care who wins and it's not really worth voting, fell by 2.6 and 1.8 percentage points respectively over this period. It is also noticeable that there are fairly large increases in the percentage of respondents indicating duty in other years in which a general election was held, specifically in 2010 (compared to 2009) and 2005 (compared to 2004) but not really in 2001 (compared to 2000). This model is only estimated for 2017 due to the availability of the question in this year and includes dummy variables indicating whether respondents thought that people should only vote if they care who wins and it is not really worth voting, with the effects of these variables measured relative to people who thought it should be everyone's duty to vote.

The third type of regret is examined by estimating binary logit models in which the dependent variable takes a value of one if the respondent stated that it should be everyone's duty to vote in a general election and zero if they gave another answer. The other two possible responses are it is not really worth voting and people should only vote if they care who wins, as indicated in the Appendix. In terms of the key variable of interest, we include a dummy variable to indicate whether the respondent appeared in the 2017 or 2015 survey, after controlling for the same explanatory variables that have been included in the multinomial logit models, with the exception of the children in the household dummy. We also estimate, for comparative purposes, equivalent logit models for several two-year periods in which a dummy variable is included for the general election year in relation to the previous year in which a general election was held. The general election years are 2001, 2005, 2010 and 2015, as well as 2017.

\section{Results}

In order to test the first form of regret, Table 3 contains the estimated coefficient and associated standard error from the key explanatory variable included in the logit model that has been estimated with the dependent variable identifying voters who would have switched how they would have voted had they been given the chance to do so again. The coefficient attached to the variable indicating whether the individual was a leave voter in the EU Referendum, relative to being a remain voter, is positive and highly significant after controlling for a range of demographic and socio-economic characteristics. ${ }^{15}$ This indicates that leave voters were significantly more likely than remain voters to report that they would have voted in a different way (i.e. in favour of remain) if there was another referendum. This is, despite the fact, that the vast majority of voters at the EU referendum would have voted in exactly the same way had they been given the chance to do so again. However, the

\footnotetext{
${ }^{15}$ The other explanatory variables are generally insignificant at the 5\% level or better. The only exceptions are the negative sign attached to London (relative to Scotland) and positive sign for Catholics (relative to those without a religion).
} 
percentage of leave voters in this regression who would have voted differently in a second referendum $(9.7 \%)$ is around double that of remain voters $(4.9 \%)$.

Table 4 presents the results from a (pooled) multinomial logit model. The coefficients and standard errors are measured relative to the base category of would vote to remain. Of most relevance to the second type of regret are the estimates associated with the explanatory variable that identifies those individuals who did not vote at the referendum. The coefficient attached to this variable is negative and significant at the $5 \%$ level in the results relating to would vote leave. This indicates that non-voters in the EU referendum are significantly less likely to vote leave, in comparison to remain, if they were given the chance to vote again. This provides fairly strong support in favour of the second type of regret. In contrast, the coefficient attached to non-voters is positive and highly significant. This is not surprising since it shows that those who did not vote at the EU referendum are significantly more likely to not vote again in comparison to voting remain.

In terms of the other estimates reported in Table 4, those relating to would vote leave if given the chance to do so again are in line with empirical studies of the actual Brexit vote (Alabrese et al, 2019; Liberini et al, 2019). In particular, those individuals indicating that they would vote leave are male, older, less qualified and reside in regions other than Scotland and London. Anglicans and other Christians are more likely to be in the would vote leave category, with these effects being significant at the $10 \%$ and $5 \%$ levels respectively. These results with regards to the effect of religion on voting in the EU referendum are consistent with Koplinskaya and Fox (2019). Respondents from an ethnic minority group are less likely to be leave voters at just the $5 \%$ level. This is also the case for students, whereas the unemployed are significantly more likely to be in the would vote leave category at the $5 \%$ level compared to the employed. Less qualified individuals are more likely to indicate that they would not vote again and older individuals also have a higher probability of being in this category when measured relative to remain voters. The regional effects for this category are generally insignificant apart from people living in Wales, the East Midlands and Yorkshire \& the Humber being less likely to vote again than those living in Scotland. This variable has positive and significant influence on the probability that the individual would not vote again.

Table 5 presents estimates from multinomial logit models that are estimated separately for voters and non-voters at the EU referendum. Considering the latter group first, it can be seen that those individuals indicating that it is everyone's duty to vote are (unsurprisingly) significantly less likely to be in the would not vote again category. This is true to a lesser extent with regards to voting leave if given the chance to do so again - although the difference is not significant when compared to 'only vote if care who wins' and at the $10 \%$ level compared to 'not worth voting'. The impact of the other explanatory variables on the probability of voting leave (or not voting) if given the chance to do so again are generally in line with those reported in Table 4, although the effects are generally less significant including for educational qualifications, as a result of the lower number of observations. 
The impact of the dummy variables that capture the respondent's view of voting in an (general) election is the same for voters but associated with higher levels of significance. This indicates that voters who think that it is everyone's duty to vote are significantly more likely to vote in an EU referendum if given the chance to do so again and to vote remain. The other influences are also generally significant in this model. These include the higher probability of voting leave amongst older and less educated individuals, whilst more educated and younger voters are more likely to vote if given the chance to do so again.

Table 6 reports the results from a binary logit model that is estimated for whether the respondent stated that it should be everyone's duty to vote in a general election. In terms of the main variable of interest, the dummy variable indicating that the individual was interviewed in 2017 (rather than 2015) is positive and significant at the 5\% level after controlling for other covariates. While we accept the evidence is suggestive and causality with the EU referendum cannot be established, the results in Table 6 can be interpreted as supporting regret type 3 in that duty significantly increases as a reported motivation for voting between 2015 and 2017. The remaining information in Table 6 relates to the changes in the incidence of respondents indicating the duty motive for voting between the other years in which a general election was held in the UK in this century prior to 2017. It can be seen that in all the other three cases, the year dummy is insignificant, which lends weight to the argument that the 2016 referendum had a significant effect on vote motivation. Heath and Goodwin (2017) analyse the 2017 general election and find that turn-out was higher in proremain areas with a younger, more ethnically diverse and graduate population. They argue that these findings were related to the Brexit decision and they are also in line with our argument made at the level of increased duty as a stated motivation for voting. Further evidence in support of this relationship is shown Table A2 in the Appendix, where it can be seen that the change in the percentage indicating that it is everyone's duty to vote was highest amongst the youngest age group (18-29 year olds) - the group that was least likely to have voted in the EU referendum.

\section{Conclusion}

This paper uses survey data to examine three forms of voter (and non-voter) regret based around the setting of the historic EU referendum that took place in the UK in June 2016. Although there is evidence of leave voters being significantly more regretful than remain voters, the majority of those who voted in the referendum would claim to vote in exactly the same way if they were given the chance to do so again. The analysis uncovers stronger evidence of regret in relation to those individuals who did not vote. This can (partly) be explained by demographics in that non-voters, who are more concentrated amongst the young, would be more likely to vote remain if given the chance to do so again. However, attitudes towards voting at an election also exert an influence, with those who think voting should be a duty being more likely to vote again as well as be in favour of remain. This is particularly true for voters but also for those that did not vote in the referendum. We also find that individuals who were interviewed in 2017 were significantly more likely to state that it is 
everyone's duty to vote in a general election, even after controlling for whether they had voted in the election.

Given how close the referendum was, the evidence presented for the three types of regret that we identify should be a cause for reflection and concern when interpreting the result of the referendum. In much of the debate that followed the referendum, the phrase the 'will of the people' was heard repeatedly and stemming from this, calls for the hard Brexit which the government subsequently pursued were justified in terms of the expression of a collective will. But the existence of widespread regret calls into question just how strongly held a large portion of individual expressions were, particularly the assumption of absence of will, that may be attributed to those that did not vote. The increase in duty as a stated motive for voting, we suggest, may be related to the referendum result and it will be interesting to see if increased democratic engagement to avoid regret after future elections or referendums will occur. 


\section{References}

Aidt, T., Grey, F. and Savu, A. (2021), "The meaningful votes: Voting on Brexit in the British House of Commons", Public Choice, 186, 587-617.

Alabrese, E., Becker, S. O., Fetzer, T. and Novy, D. (2019), "Who voted for Brexit? Individual and regional data combined", European Journal of Political Economy, 56, 132-150.

Arnorsson, A. and Zoega, G. (2018), "On the causes of Brexit", European Journal of Political Economy, 55, 301-323.

Becker, S. O., Fetzer, T. and Novy, D. (2017), "Who voted for Brexit? A comprehensive district-level analysis", Economic Policy, 32(92), 601-650.

Blais, A. and Galais, C. (2016), "Measuring the civic duty to vote: A proposal", Electoral Studies, 41, 60-69.

Bol, D., Blais, A. and Laslier, J. F. (2018), "A mixed-utility theory of vote choice regret", Public Choice, 176, 461-478.

Born, B., Muller, G. J., Schularick, M. and Sedlacek, P. (2019), "The costs of economic nationalism: Evidence from the Brexit experiment", Economic Journal, 129, 2722-2744.

Carreras, M. (2019), “'What do we have to lose?' Local economic decline, prospect theory, and support for Brexit”, Electoral Studies, 62, 102094.

Carreras, M., Irepoglu Carreras, Y. and Bowler, S. (2019), "Long-term economic distress, cultural backlash, and support for Brexit", Comparative Political Studies, 52(9), 1396-1424.

Chen, W., Los, B., McCann, P., Ortega-Argilés, R., Thissen, M. and van Oort, F. (2018), “The continental divide? Economic exposure to Brexit in regions and countries on both sides of The Channel", Papers in Regional Science, 97(1), 25-54.

Clarke, H. D., Goodwin, M. and Whiteley, P. (2017), Brexit: Why Britain Voted to Leave the European Union, Cambridge University Press, Cambridge.

Colantone, I. and Stanig, P. (2018), "Global competition and Brexit", American Political Science Review, 112(2), 201-218.

Drinkwater, S., and Jennings, C. (2007), “Who are the expressive voters?”, Public Choice, 132, 179-189.

Fetzer, T. (2019), “Did austerity cause Brexit?”, American Economic Review, 109(11), 38493886.

Ferejohn, J. A. and Fiorina, M. P. (1974), "The paradox of not voting: A decision theoretic analysis", American Political Science Review, 69, 920-925.

Ford, R. and Goodwin, M. (2017), "Britain after Brexit: A nation divided", Journal of Democracy, 28(1), 17-30. 
Goodman, N. (2018), “The conditional duty to vote in elections”, Electoral Studies, 53, 39-47.

Goodwin, M. and Heath, O. (2016), "The 2016 referendum, Brexit and the left behind: An aggregate-level analysis of the result", The Political Quarterly, 87(3), 323-332.

Goodwin, M., Hix, S. and Pickup, M. (2020), "For and against Brexit: A survey experiment of the impact of campaign effects on public attitudes toward EU membership", British Journal of Political Science, 50(2), 481-495.

Goodwin, M. and Milazzo, C. (2017), "Taking back control? Investigating the role of immigration in the 2016 vote for Brexit", British Journal of Politics and International Relations, 19(3), 450-464.

Green, J., Hellwig, T. and Fieldhouse, E. (2021), "Who gets what: The economy, relative gains and Brexit", British Journal of Political Science, forthcoming.

Hamlin, A. and Jennings, C. (2011), "Expressive political behaviour: Foundations, scope and implications", British Journal of Political Science, 41, 645-670.

Hamlin, A. and Jennings, C. (2019), "Expressive voting" in R. Congleton, B. Grofman and S. Voigt (Eds) Oxford Handbook of Public Choice: Volume 1, Oxford University Press, Oxford, 333-350.

Heath, O. and Goodwin, M. J. (2017), "The 2017 General Election, Brexit and the return to two-party politics: An aggregate-level analysis of the result", Political Quarterly, 88(3), 345358.

Hur, A. (2017), "Is there an intrinsic duty to vote? Comparative evidence from East and West Germans", Electoral Studies, 45, 55-62.

Hobolt, S. B. (2016), “The Brexit vote: A divided nation, a divided continent", Journal of European Public Policy, 23(9), 1259-1277.

Hobolt, S. B., Leeper, T. J. and Tilley, J. (2021), "Divided by the vote: Affective polarization in the wake of the Brexit referendum", British Journal of Political Science, forthcoming.

Johnson, P. and Mitchell, I. (2017), "The Brexit vote, economics, and economic policy”, Oxford Review of Economic Policy, 33, S12-S21.

Kolpinskaya, E. and Fox, S. (2019), "Praying on Brexit? Unpicking the effect of religion on support for European Union integration and membership", Journal of Common Market Studies, 57(3), 580-598.

Liberini, F., Oswald, A. J., Proto, E. and Redoano, M. (2019), "Was Brexit triggered by the old and unhappy? Or by financial feelings?", Journal of Economic Behavior \& Organization, 161, 287-302.

Norris, P. and Ingelhart, R. (2019), Cultural Backlash: Trump, Brexit and Authoritarian Populism, Cambridge University Press, Cambridge. 
Powdthavee, N., Plagnol, A. C., Frijters, P. and Clark, A. E. (2019), "Who got the Brexit blues? The effect of Brexit on subjective wellbeing in the UK", Economica, 86(343), 471-494.

Riker, W. H. and Ordeshook, P. C. (1968), "A theory of the calculus of voting”, American Political Science Review, 62, 25-42.

Rudolph, L. (2020), "Turning out to turn down the EU: The mobilisation of occasional voters and Brexit", Journal of European Public Policy, 27(12), 1858-1878.

Sampson, T. (2017), "Brexit: The economics of international disintegration", Journal of Economic Perspectives, 31(4), 163-84.

Schwartz, C., Simon, M., Hudson, D. and van-Heerde-Hudson, J. (2021), “A populist paradox? How Brexit softened anti-immigrant attitudes", British Journal of Political Science, forthcoming.

Sobolewska, M. and Ford, R. (2020). Brexitland: Identity, Diversity and the Reshaping of British Politics, Cambridge University Press, Cambridge. 
Table 1: Responses to Questions on Whether Voted in the EU Referendum and How Would Vote if given the Chance to Again

\begin{tabular}{lcccccc}
\hline \hline \multirow{2}{*}{$\begin{array}{l}\text { How would vote if given chance } \\
\text { to again }\end{array}$} & \multicolumn{5}{c}{ Did you manage to vote in the EU Referendum? } \\
\cline { 2 - 7 } & Yes & No & $\begin{array}{c}\text { Prefer not } \\
\text { to say }\end{array}$ & $\begin{array}{c}\text { Don't } \\
\text { remember }\end{array}$ & $\begin{array}{c}\text { Don't Know/ } \\
\text { Refusal }\end{array}$ & Total \\
\hline Remain a member of the EU (\%) & 51.9 & 38.8 & 7.7 & 28.8 & 24.2 & 48.4 \\
Leave the EU (\%) & 42.9 & 22.8 & 7.7 & 23.7 & 6.1 & 37.8 \\
I would not vote (\%) & 1.7 & 28.9 & 23.1 & 13.6 & 6.1 & 8.1 \\
Prefer not to say (\%) & 0.9 & 1.2 & 46.2 & 1.7 & 0.0 & 1.1 \\
DK/Refusal (\%) & 2.6 & 8.3 & 15.4 & 32.2 & 63.6 & 4.7 \\
\hline $\mathrm{N}$ (Unweighted) & 3,764 & 1,125 & 13 & 59 & 33 & 4,994 \\
\hline \hline
\end{tabular}

Table 2: Responses to Questions on How Voted in the EU Referendum and How Would Vote if given the Chance to Again

\begin{tabular}{lcccccc}
\hline \hline \multirow{2}{*}{$\begin{array}{l}\text { How would vote if given } \\
\text { chance to again }\end{array}$} & Remain & Leave & $\begin{array}{c}\text { Prefer not } \\
\text { to say }\end{array}$ & $\begin{array}{c}\text { Don`t } \\
\text { remember }\end{array}$ & $\begin{array}{c}\text { Don't Know/ } \\
\text { Refusal }\end{array}$ & Total \\
\cline { 2 - 7 } & 92.9 & 9.3 & 13.6 & 5.6 & 4.4 & 51.9 \\
\hline Remain a member of the EU (\%) & 4.8 & 85.2 & 4.6 & 22.2 & 4.4 & 42.9 \\
Leave the EU (\%) & 0.7 & 2.3 & 13.6 & 27.8 & 4.4 & 1.7 \\
I would not vote (\%) & 0.1 & 0.7 & 59.1 & 11.1 & 21.7 & 0.9 \\
Prefer not to say (\%) & 1.5 & 2.6 & 9.1 & 33.3 & 65.2 & 2.6 \\
DK/Refusal (\%) & 1,921 & 1,780 & 22 & 18 & 23 & 3,764 \\
\hline N (Unweighted)
\end{tabular}

Table 3: Logit Estimates of Vote Switching if Given Chance to Vote Again

\begin{tabular}{lcc}
\hline \hline & Coefficient & Marginal Effect \\
\hline Voted Leave at the Referendum & $\begin{array}{c}0.743^{* * *} \\
(0.169)\end{array}$ & $\begin{array}{l}0.045^{* * *} \\
(0.010)\end{array}$ \\
\hline Pseudo R-Squared & 0.041 \\
$\mathrm{~N}$ & & 3,538 \\
\hline \hline
\end{tabular}

Notes: Model also controls for gender, age, education, region, marital status, children in household, ethnicity, religion, economic activity and year of interview. Robust standard errors in parentheses. ${ }^{* * *}$ indicates significance at the $1 \%$ level based on two-tailed tests. 
Table 4: Multinomial Logit Estimates of How Would Vote if Given Chance Again

\begin{tabular}{|c|c|c|c|c|c|}
\hline & \multirow{2}{*}{ Mean } & \multicolumn{2}{|c|}{ Would Vote Leave } & \multicolumn{2}{|c|}{ Would Not Vote } \\
\hline & & Coef. & S.E. & Coef. & S.E. \\
\hline Did not vote in Referendum & 0.219 & $-0.199^{* *}$ & 0.100 & $3.100^{* * *}$ & 0.166 \\
\hline Female & 0.546 & $-0.394^{* * *}$ & 0.071 & -0.119 & 0.138 \\
\hline First Degree & 0.267 & $-1.405^{* * *}$ & 0.115 & $-1.664^{* * *}$ & 0.235 \\
\hline Higher Ed. below degree & 0.115 & $-0.515^{* * *}$ & 0.124 & $-0.722^{* * *}$ & 0.256 \\
\hline A level or equivalent & 0.156 & $-0.556^{* * *}$ & 0.120 & $-0.594^{* * *}$ & 0.213 \\
\hline O level or equivalent & 0.174 & 0.015 & 0.116 & -0.286 & 0.201 \\
\hline $\mathrm{CSE}$ or equivalent & 0.077 & 0.070 & 0.147 & 0.340 & 0.238 \\
\hline Foreign or other qualification & 0.018 & $-0.525^{* *}$ & 0.257 & -0.343 & 0.402 \\
\hline Age 30-39 & 0.166 & $0.371^{* *}$ & 0.155 & $0.401^{*}$ & 0.227 \\
\hline Age $40-49$ & 0.163 & $0.566^{* * *}$ & 0.156 & $0.448^{*}$ & 0.243 \\
\hline Age $50-59$ & 0.163 & $0.654^{* * *}$ & 0.158 & $0.562^{* *}$ & 0.260 \\
\hline Age $60-69$ & 0.180 & $0.830^{* * *}$ & 0.179 & $0.596^{*}$ & 0.325 \\
\hline Age 70 and over & 0.213 & $0.850^{* * *}$ & 0.204 & 0.680 & 0.415 \\
\hline North East & 0.048 & $0.727^{* * *}$ & 0.197 & 0.410 & 0.341 \\
\hline North West & 0.123 & $0.644^{* * *}$ & 0.159 & 0.334 & 0.286 \\
\hline Yorkshire \& the Humber & 0.100 & $0.842^{* * *}$ & 0.167 & $0.738^{* * *}$ & 0.286 \\
\hline East Midlands & 0.086 & $0.727^{* * *}$ & 0.171 & $0.720^{* *}$ & 0.296 \\
\hline West Midlands & 0.085 & $0.889^{* * *}$ & 0.170 & 0.221 & 0.332 \\
\hline East of England & 0.101 & $0.421^{* * *}$ & 0.165 & -0.342 & 0.335 \\
\hline South West & 0.097 & $0.681^{* * *}$ & 0.165 & 0.060 & 0.313 \\
\hline London & 0.099 & 0.007 & 0.175 & 0.011 & 0.321 \\
\hline South East & 0.134 & $0.469^{* * *}$ & 0.156 & -0.283 & 0.307 \\
\hline Wales & 0.049 & $0.736^{* * *}$ & 0.197 & $0.923^{* * *}$ & 0.332 \\
\hline Living as Married & 0.100 & $-0.295^{* *}$ & 0.128 & -0.038 & 0.230 \\
\hline Separated or Divorced & 0.133 & -0.031 & 0.107 & 0.154 & 0.207 \\
\hline Widowed & 0.101 & -0.099 & 0.127 & 0.426 & 0.305 \\
\hline Not Married & 0.210 & -0.047 & 0.109 & 0.189 & 0.187 \\
\hline Children in household & 0.672 & -0.093 & 0.091 & -0.093 & 0.166 \\
\hline Ethnic Minority & 0.104 & $-0.381^{* *}$ & 0.150 & $-0.581^{* *}$ & 0.259 \\
\hline Roman Catholic & 0.072 & -0.101 & 0.139 & -0.324 & 0.266 \\
\hline Church of England/Anglican & 0.167 & $0.178^{*}$ & 0.098 & -0.126 & 0.230 \\
\hline Other Christian & 0.186 & $0.223^{* *}$ & 0.095 & 0.097 & 0.177 \\
\hline Other Religion & 0.059 & -0.208 & 0.193 & -0.213 & 0.329 \\
\hline Unemployed & 0.043 & $0.561^{* * *}$ & 0.184 & 0.056 & 0.284 \\
\hline Student & 0.024 & $-0.682^{* *}$ & 0.301 & $-1.280^{* *}$ & 0.565 \\
\hline Permanently Sick & 0.040 & $0.324^{*}$ & 0.193 & $0.566^{* *}$ & 0.270 \\
\hline Retired & 0.317 & 0.118 & 0.129 & -0.280 & 0.305 \\
\hline Looking after the home & 0.053 & 0.145 & 0.161 & 0.342 & 0.238 \\
\hline Other economic activity & 0.001 & 0.158 & 0.363 & 0.775 & 0.527 \\
\hline
\end{tabular}




\begin{tabular}{lccccc} 
Interviewed in 2018 & 0.019 & -0.092 & 0.090 & 0.209 & 0.170 \\
Interviewed in 2019 & 0.208 & -0.093 & 0.084 & 0.117 & 0.172 \\
Constant & - & $-0.585^{* * *}$ & 0.225 & $-3.424^{* * *}$ & 0.395 \\
\hline Pseudo R-Squared & & \multicolumn{5}{c}{0.189} \\
\hline $\mathrm{N}$ & & \multicolumn{5}{c}{4,626} \\
\hline \hline
\end{tabular}

Notes: Reference categories are No Qualifications, Aged 18-29, Scotland, Married, No Religion, Employed and Interviewed in 2017. ${ }^{* * *},{ }^{* *}$ and ${ }^{*}$ indicate significance at the $1 \%, 5 \%$ and $10 \%$ levels respectively using robust standard errors and two-tailed tests. 


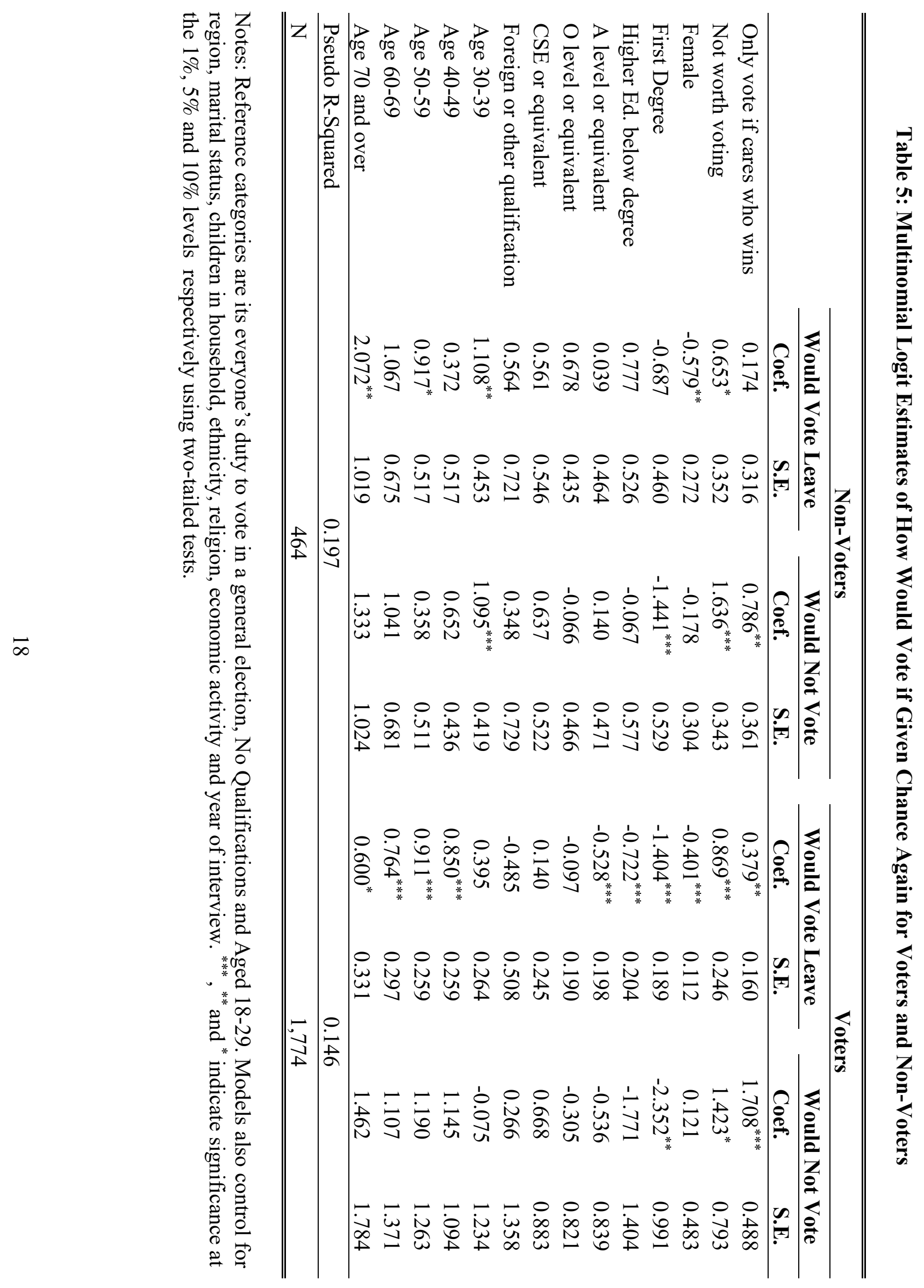




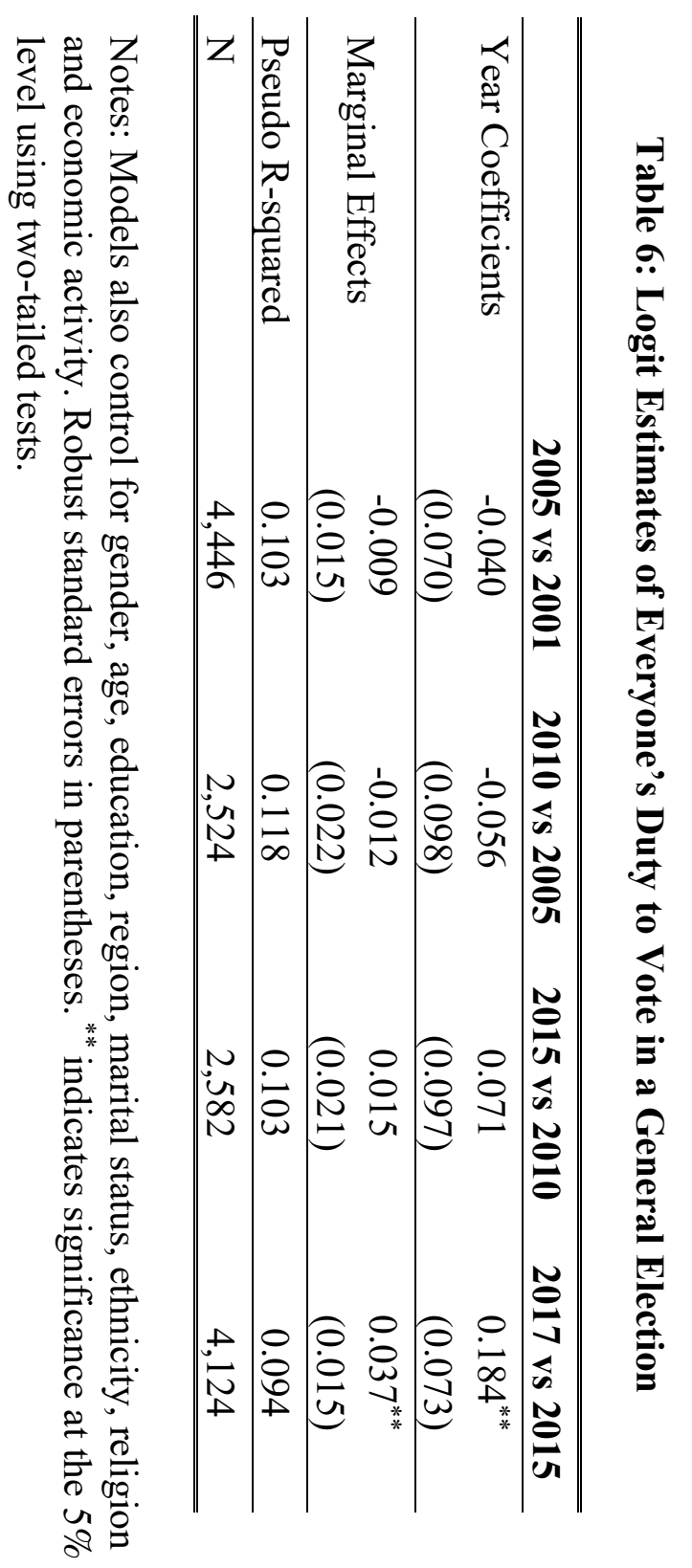


Appendix

Question about whether voted in the 2016 EU Referendum:

Did you manage to vote in the referendum about the European Union?

Question about how voted in the 2016 EU Referendum:

Did you vote to 'remain a member of the EU' or to 'leave the EU'?

Question (and responses) on voting in EU Referendum if given another chance:

If you were given the chance to vote again, how would you vote - to remain a member of the EU, to leave the EU, or would you not vote?

Question (and responses) on voting in a General Election:

About general elections. Which of comes closest to your view ... In a general election it's not really worth voting OR people should vote only if they care who wins OR it's everyone's duty to vote? 


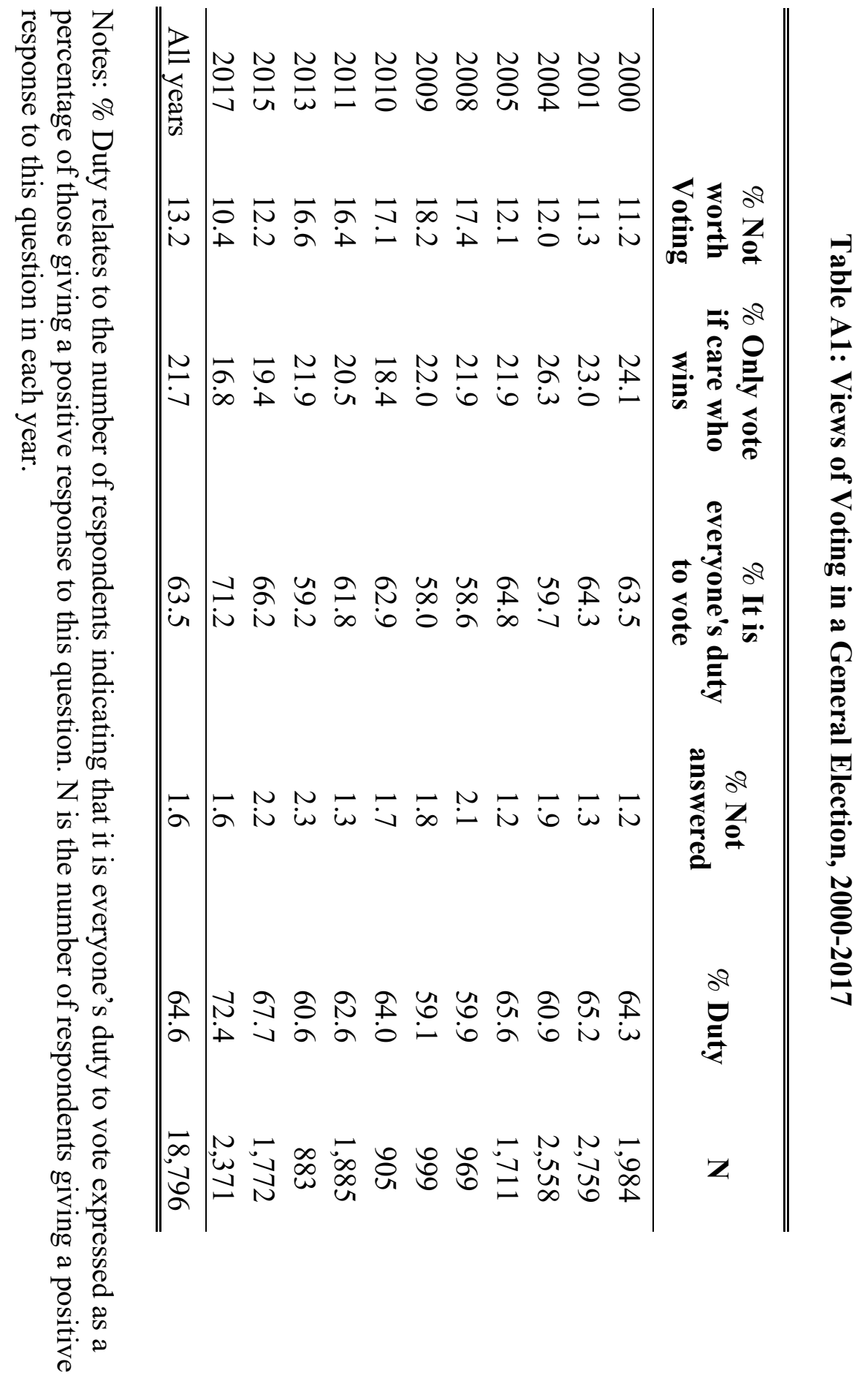




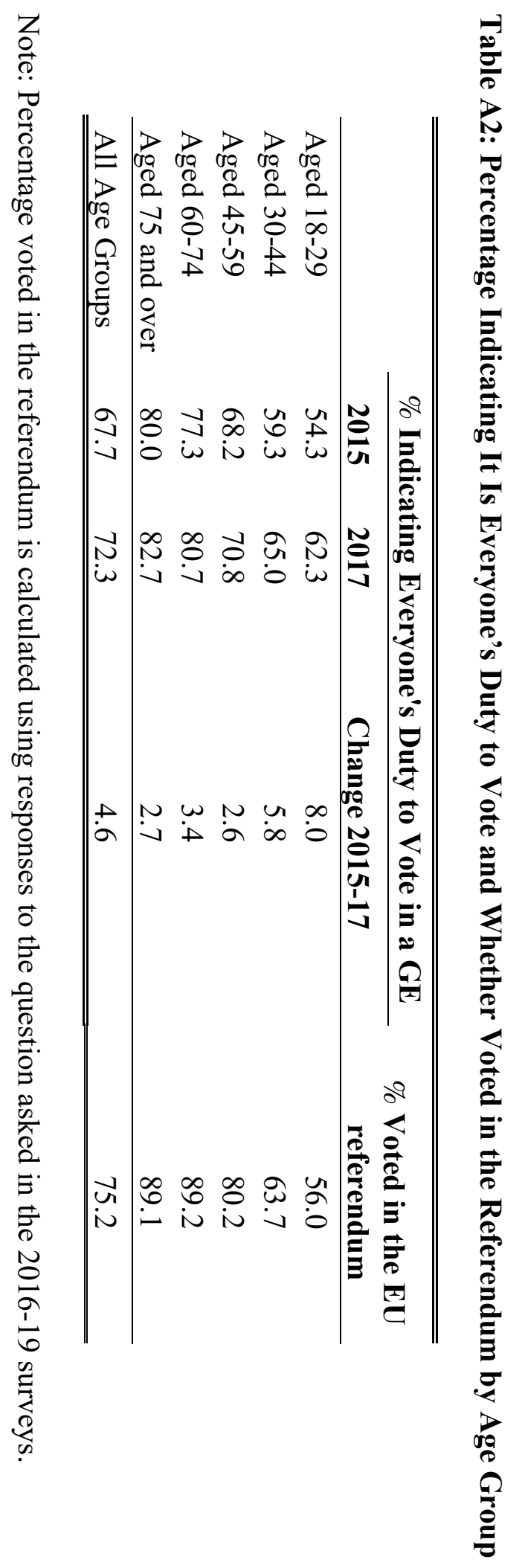

